\title{
Participatory Rural Appraisal in Deliberations of Development Planning
}

\author{
Ahmad Mustanir \\ Dept. of Government \\ Sekolah Tinggi Ilmu Social dan Ilmu Politik \\ Muhammadiyah Rappang \\ PO Box 91651, Sidrap - South Sulawesi, Indonesia \\ E-mail: ahmadmustanir74@gmail.com \\ Barisan \\ Dept. of Government \\ Sekolah Tinggi Ilmu Social dan Ilmu Politik \\ Muhammadiyah Rappang \\ PO Box 91651, Sidrap - South Sulawesi, Indonesia \\ E-mail: uchenklppmstisip@yahoo.co.id
}

\author{
Sandi Lubis \\ Dept. of Government \\ Sekolah Tinggi Ilmu Social dan Ilmu Politik \\ Muhammadiyah Rappang \\ PO Box 91651, Sidrap - South Sulawesi, Indonesia \\ E-mail: sandi.lubis7@gmail.com
}

\begin{abstract}
This research is essential to understand the use of Participatory Rural Appraisal (PRA) method in deliberations of development planning. The result of observation showed that the activity of deliberations of development planning has not worked optimally. It is due to the unclear usage of tools to seek the priority activity based on the finding problems. The proposals more likely came from observation instead of the results of research from each field and subject. The proposals mostly were brought by people who have influence or close relation with apparatus of village government. The society was not involved widely in digging the problems. With PRA method, deliberations of village development planning are expected to be more participative conducted with the wide involvement of society based on their own background field. With such problem and objective, it will give benefit in figuring out thee application of PRA method in deliberations of development planning. In order to achieve the objective, the methods needed to be conducted are observation, interview, and literature study. The result of the research showed that the application of PRA method has not been work optimally. The application of PRA is limited within direct deliberations of development planning in village level without involving the wide society starting from the lowest level like group of society or neighborhood association (RT). Deliberation to determine the development proposal has not been through problem analysing process through study in related field. However, it only listens to ideas of the present society
\end{abstract}

Keywords-Deliberations of Development Planning, Participatory Rural Appraisal, Participative Development Planning

\section{INTRODUCTION}

Based on the observation, deliberations of development planning did not run well. There are many government programs which overlapped each other. The programs which will be applied in a certain area are always approached through repeated problem searching method to find out the society's needs. The deliberations also did not use definite tools to arrange the priority of the programs. The programs suggestion mostly came from particular people and did not involve the society in a bigger scale that come from many levels such as Rukun Tetangga (RT), Rukun Warga (RW) and village.

According to [18] deliberations of development planning is development planning cooperatively with the society, a guidance or model of development which emphasize the participation of the society in its whole process. Deliberations of development planning contains definitions as follows: 1) Planning as series of analytic process starts from identification of society's needs to establishment of development program. 2) planning of environment development, the programs in improving welfare, safety, prosperity and peace of society in residential environment from the level of RT/RW to the level of hamlet and village. 3) development planning is based on problems, needs, aspiration and local human resource. 4) manifestation of society's participation in development planning.

Deliberations of development planning is open multiparties' forums which identify and decide the priority of society development policies [9].

The definition of society's participation is the involvement of society member in the process of planning and implementation of development program which is done within the society [I], [6], [15], [20].

The scope of participation by considering the arrangement of development planning process. Based on their explanation, the types of participation can be divided as follows: 1) Participation in decision-making; 2) Participation in implementing; 3) Participation in monitoring and evaluating 
the program; 4) Participation in utilizing the outcome of development [7], [II].

Society is a group of people that unified feelings due to their sharing of identity, interests, feeling of possession, and, usually, living place [17]

PRA is participatory approaches and methods which emphasize the local knowledge and allow the society to do their own appraisal, analysis and planning. PRA uses visualization and exercise to facilitate information-sharing, analysis and action between the stakeholders [22].

PRA is the most suitable and appropriate method to identify the existing situation of the community [3].

The World Bank Explained that PRA is a process which extends into analysis, planning and action. Defines PRA as a 'family of participatory approaches and methods which emphasize local knowledge and enable local people to do their own appraisal, analysis and planning. 'PRA uses group animation and exercises to facilitate information sharing, analysis and action among stakeholders [23].

PRA method as an alternative for development practitioners who need a research methodology which can help them to understand the society quickly, with actual information and low cost, while allow them to persuade people to become the executants of the research [4].

PRA has several basic principles such as: mutual learning and experience sharing, the involvement of whole people, the implementation of triangulation and the continuity of the program [14], [19], [12], [2I].

The stages of PRA implementation are described briefly as follows: 1) searching of the village condition from time to time; 2) registering seasonal calendar based on people's custom; 3) visualizing the village area mapping; 4) transecting; 5) creating Venn diagram (institutional relation chart); 6) reviewing the livelihood of the people; 7) creating ranking matrix (ratings chart); 8) arranging the specific activities plan in the village [19].

This research focused on the use of Participatory Rural Appraisal (PRA) method in deliberations of development planning at Tonrong Rijang village, Baranti district, Sidenreng Rappang regency.

\section{RESEARCH METHODS}

The type of research used is descriptive explanatory research which is a combination of descriptive research and explanatory research of [13].

This research used qualitative approach. The characteristic model of qualitative research will greatly facilitate the researcher in finding and understanding the research question. As mentioned by Creswell researchers can use multiple methods that are interactive and humanistic [5] proposed the reasons for using qualitative methods because this approach has advantages in exposing the phenomenon of the prevalent custom of community participation in development planning. Furthermore, because the qualitative approach has a high flexibility for researchers when determining the steps of research, qualitative research can also provide opportunities for greater expression and explanation in the form of interpretation based on logical intuitive certainty.

In qualitative research, the researcher can also simultaneously act as a participant observer with activities such as taking notes, recording and observing [2].

There are several data collection techniques in this study, namely Observation, in-depth interview (in-depth interview) and Library Studies (library research). In order to test the validity of data, the researcher uses triangulation method where the data were obtained from several resources.

Data analysis technique used in this research is Interactive Model Analysis (Interactive Model Of Analysis) developed by Miles and Huberman. The technique suggests that activities in qualitative data analysis are performed interactively and continuously until it is complete, so that the data is saturated. Activities in data analysis contain of Collection Data, Reduction Data, Display Data, and Conclusion Drawing / Verifying [9], [16].

Triangulation of data is a technique of checking the validity of data that utilizes something else outside the data for the purposes of checking or as a comparison of the data [12]. In this term, Patton in [2I] stated that there are four kinds of triangulation techniques, namely: data triangulation, triangulation method, triangulation of researchers, and triangulation theory. Triangulation types used in this research are triangulation of data source and method.

\section{RESULTS AND DISCUSSION}

This research was done at Tonrong Rijang village, Baranti district, Sidenreng Rappang regency, South Sulawesi province. The village one of the targeted villages of Sekolah Tinggi Ilmu Social dan Ilmu Politik Muhammadiyah Rappang. In one of the accompaniment activity to formulate a development planning program, the village has already used PRA method

A. PRA on the series of analysis activity started from society's needs identification to development program establishment

The research showed that the term of PRA as a method in participatory planning program was unrecognized by the society before. While some methods which are the part of PRA has been commonly used in deliberations of development planning at the village. As described by the village secretary, Abdul Asis:

"I was confused at the first time I heard of the term of PRA. After knowing it, I thought that it is good to identify the potencies and problems within the society and it is easy to understand. Compared to the previous method, I thought that PRA is better and more effective, more complete and its problems review analysis is easier to understand in every 
field. Very effective and interesting. The society can easily establish a development planning program at their village. (an interview on 10 May 2017)."

From the identification of problems to the establishment of the program, basic principles of PRA such as: mutual learning and experience sharing, the involvement of whole people, the implementation of triangulation and the continuity of the program tended to be ignored. The established programs mostly came from the suggestion of the public figures which was based on subjective appraisal without doing the triangulation on the field previously. The involvement of the society was very minimal where the ones that attended the village meetings only were involved. There were just certain public figures and village apparatus that were invited to the village meetings. Mutual learning process and experiences sharing were also very minimal because the suggested programs in deliberations of development planning were not deliberated deeper based on the study on each fields.

In contrast, on the accompaniment program of society empowerment, the use of PRA method which uses more defined tools was more preferred by the society rather than submission of opinion method in deliberations of development planning. As stated by Haruna Rio, the head of Village Consultative Bodies (Badan Permusyawaratan Desa):

"I found that preferred the PRA model rather than counseling or submission of opinion which bored people quickly, in contrast, PRA kept the society active in submitting their opinion with clear tools/criteria, it was also effective on its implementation. In PRA, all people who involved conveyed their opinion so everything that happened in deliberations of development planning and what people wanted could be conveyed on the whole. (an interview on 7 M ay 2017)."

B. PRA on environment deliberations of development planning, society welfare, safety, prosperity, and peace on residential environment from $R T / R W$, hamlet and village level

PRA on the deliberations of development planning which was held at Tonrong Rijang also talked about all development aspects such as environment, the programs to improve the welfare, safety, prosperity of the society on the field of economy, physical environment, social, etc. Even though the dominant established programs on deliberations of development planning were physical development, the programs establishment seemed to consider the representation of programs plan from the level of RT/RW and hamlet under excuse of fairness and equity.

The fairness in a program establishment from PRA method is not based on spatial division, but it is based on the study of the problems and potencies on the intended field.

The deliberations of development planning was not held on the level of RT, RW and hamlet, but was held on the level of village directly. As a result, the involvement of people on deliberations of development planning was not equal and thorough.

\section{PRA on deliberations of development planning oriented to the problems, needs, aspirations, and local human resources}

On the deliberations of development planning, there were no defined tools used so it was far from the participatory principles of PRA. Based on the research findings, the programs establishment which did not use the PRA method resulted in the overlapping programs. The problems identification to find out the society needs was done repeatedly whenever a new program will be established. Suggested development plan which has been conveyed previously will usually be conveyed again in different meetings.

The obscurity of the tools and method which were used on deliberations of development planning resulted in the development planning was not oriented to the problems, needs, aspirations and existing potencies on the whole. Besides, the use of fixed tools or method on a development planning is essential for the society in running other programs.

The village secretary of Desa Tonrong Rijang, Abdul Asis uttered that:

"With PRA method, people felt more open and comfortable to share any information. Moreover, people are happy if there are outsiders who can help them to convey their opinion. It is obvious that they feel more active and easier. By using PRA method, people will be brave to convey all the problems and potencies at the village as well as the needs." (an interview at 10 May 2017)

\section{PRA as the manifestation of the society on deliberations of development planning}

Society Participation on deliberations of development planning which was held at Tonrong Rijang did not fulfill all the basic principles of PRA method such as: mutual learning and experience sharing, the involvement of all people, the implementation of triangulation and the continuity of the program. It was the result of the execution processes on the village level which were run 'instantly'. There was fixed pattern which occurred continuously where the village government offered the existing programs plans. The plans then were conveyed to the people to be accepted.

From these stages of PRA implementation: 1) searching of the village condition from time to time; 2 ) registering seasonal calendar based on people's custom; 3) visualizing the village area mapping; 4) transecting; 5) creating Venn diagram (institutional relation chart); 6) reviewing the livelihood of the people; 7) creating ranking matrix (ratings chart); 8) arranging the specific activities plan in the village; there were no any stages that were passed. This phenomenon came in contrast with what village head of Tonrong Rijang, Abdul Kadir said:

"All the running program, either the PRA which has been done at the accompaniment program or what PNPM and village government have done on development planning have run well and effectively (an interview on 23 April 2017)." 


\section{CONCLUSION}

The conclusions of this study are as follows:

1. From the identification of problems to the establishment of the program, basic principles of PRA such as: mutual learning and experience sharing, the involvement of whole people, the implementation of triangulation and the continuity of the program tended to be ignored. The established programs mostly came from the suggestion of the public figures which was based on subjective appraisal without doing the triangulation on the field previously. The involvement of the society was very minimal where the ones that attended the village meetings only were involved. There were just certain public figures and village apparatus that were invited to the village meetings. Mutual learning process and experiences sharing were also very minimal because the suggested programs in deliberations of development planning were not deliberated deeper based on the study on each fields.

2. PRA on the deliberations of development planning which was held at Tonrong Rijang also discussed about all development aspects such as environment, the programs to improve the welfare, safety, prosperity of the society on the field of economy, physical environment, social, etc. Even though the dominant established programs on deliberations of development planning were physical development, the programs establishment seemed to consider the representation of programs plan from the level of RT/RW and hamlet under excuse of fairness and equity. The fairness in a program establishment from PRA method is not based on spatial division, but it is based on the study of the problems and potencies on the intended field. The deliberations of development planning was not held on the level of RT, RW and hamlet, but was held on the level of village directly. As a result, the involvement of people on deliberations of development planning was not equal and thorough

3. On the deliberations of development planning, there were no defined tools used so it was far from the participatory principles of PRA. Based on the research findings, the programs establishment which did not use the PRA method resulted in the overlapping programs. The problems identification to find out the society needs was done repeatedly whenever a new program will be established. Suggested development plan which has been conveyed previously will usually be conveyed again in different meetings

4. Society Participation on deliberations of development planning which was held at Tonrong Rijang did not fulfill all the basic principles of PRA method such as: mutual learning and experience sharing, the involvement of all people, the implementation of triangulation and the continuity of the program. It was the result of the execution processes on the village level which were run 'instantly'. There was fixed pattern which occurred continuously where the village government offered the existing programs plans. The plans then were conveyed to the people to be accepted. There were no any stages that were passed

\section{REFERENCES}

[1] Adisasmita, R. (2006). Membangun Desa Partisipatif. Yogyakarta: Graha Ilmu.

[2] Ahmad, J. (2015). Metode Penelitian Administrasi Publik Teori dan Aplikasi. Yogyakarta: Gava Media.

[3] Alam, A. and Ishan, S. 2012. Role of Participatory Rural Appraisal in Community Development (A Case Study of Barani Area Development Project in Agriculture, Live Stock and Forestry Development in Kohat). Int. J. Acad. Res. Busi. \& Soc. Sci. 2 (8): h. 25-38.

[4] Chambers, R. (2007). From PRA to PLA and Pluralism: Practice and Theory. Working Paper \#286, Institute of Development Studies, University of Sussex, Sussex, UK. h. 7-12.

[5] Creswell, J.W. (penerjemah Achmad Fawaid). (2013). Research Design Pendekatan Kualitatif, Kuantitatif dan Mixed. Yogyakarta : Pustaka Pelajar.

[6] Isbandi. (2007). Participatory planning with ethnic minorities asset-based: from thought to implementation. Depok: FISIP UI Press

[7] Mardikanto, T and Soebiato, P. (2015). Pemberdayaan Masyarakat Dalam Perspektif Kebijakan Publik. Bandung : Alfabeta

[8] Moeliono and Djohani Rianingsih. (1996). Kebijakan dan Strategi Penerapan PRA dalam Pengembangan Program. Driya Media. Bandung.

[9] Moleong, L.J. (2006). Metodologi Penelitian Kualitatif. Bandung: PT. Remaja Rosdakarya

[10] Mustanir, A. 2017. Participation of Ethnic Community Towani Tolotang in Deliberation of Development Plan. Proceedings, Advances in Social Science, Education and Humanities Research, Vol 84. Publisher: Atlantis Press. ISBN 978-94-6252-321-0. ISSN 2352-5398. h 356.

[II] Mustanir, A. 2016. Perencanaan Mewujudkan Kehidupan Pemerintahan dan Sosial Yang Islami di Desa Tonrong Rijang Kabupaten Sidenreng Rappang. Prosiding Seminar Nasional Reformasi dan Inovasi Tata Kelola Pemerintahan. Samarinda : Fisip Universitas Mulawarman. ISBN 978-602-60786-0-5. h 294.

[12] Narayanasamy, N. 2009. Participatory Rural Appraisal Principles, Methods and Application. Second Edition. First Published. ISBN: 97881-7829-885-6 (PB) h. 32

[13] Punch, K. 2006. Developing Effective Research Proposals, Second Edition. Sage Publication, p. 33-35

[14] Rochdyanto, S. (2000). Langkah-langkah Pelaksanaan Metode PRA. Makalah ToT PKPI. Yogyakarta

[15] Slamet, Y. (2002). Konsep-Konsep Dasar Partisipasi Sosial. Yogyakarta: PAU-SS UGM.

[16] Sugiyono. (2015). Metode Penelitian Kombinasi. Cetakan Ke 7. Bandung : Alfabeta.

[17] Suharto, E. (2006). Membangun Masyarakat Memberdayakan Rakyat. Bandung : Refika Aditama.

[18] Sumpeno, W. (2008). Perencanaan Desa Terpadu (Panduan Perencanaan Pembangunan Berbasis Masyarakat). Jakarta : CRS Indonesia.

[19] Supriatna, A. 2014. Relevansi Metode Participatory Rural Appraisal Dalam Mendukung Implementasi Undang-Undang Pemerintahan Desa. Jurnal Lingkar Widyaiswara. Edisi 1 No. 1, Jan - Mar 2014, p.39-45

[20] Suryono, A. (2001). Teori dan Isu Pembangunan. Jakarta : UM Press.

[2I] Sutopo, HB. (2002). Metode Penelitian Kualitatif. Surakarta: UNS Press

[22] Uddin, M.N. and N. Anjuman. 2013. Participatory rural appraisal approaches: an overview and an exemplary application of focus group discussion In climate change adaptation and mitigation strategies. Int. J. Agril. Res. Innov. \& Tech. 3 (2): 72-78, December, 2013.

[23] World Bank. 1995. The Participation Sourcebook. Washington DC : World Bank. p. 175. 